Historic, Archive Document

Do not assume content reflects current scientific knowledge, policies, or practices. 



\section{FALL OF 1918}

\section{Wholesale}

Trade Catalogue

FOR NURSERYMEN and FLORISTS ONLY

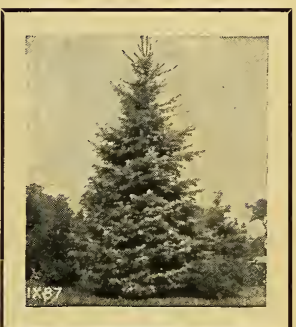

L. A. BERCKMANS, Receiver for

P. J. Berckmans Company INCORPORATED

ESTABLISHED IN 1856

\section{部}

FRUITLAND NURSERIES

AUGUSTA, GEORGIA 


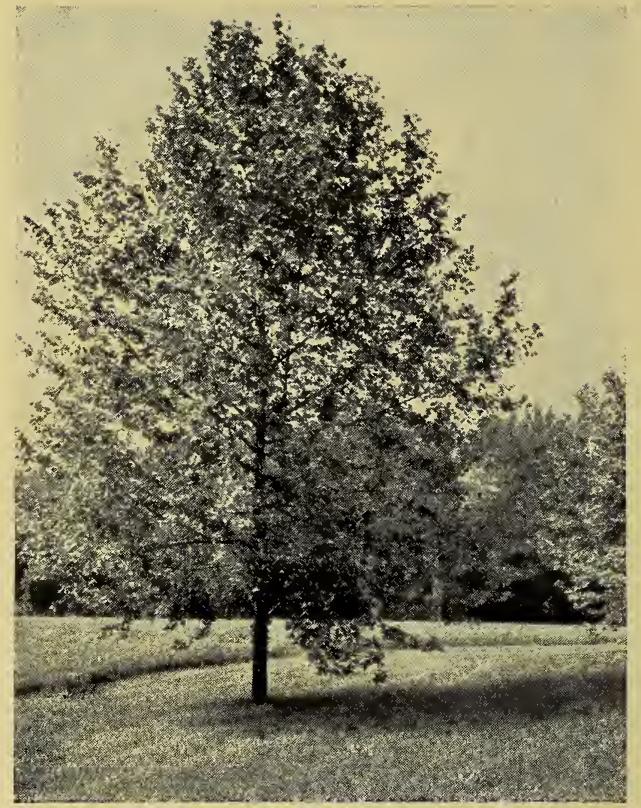

Platanus occidentalis (American Sycamore) 


\section{A Word of Explanation to Our Customers}

In all probability this price-list will be the last to be published by the old firm of P. J. Berckmans Company.

In March of this year, announcement was made of the expiration, by legal limitation, of the charter held by the company, and the desire of the stockholders to close the affairs of the corporation.

To conform to the Georgia laws governing corporations, Mr. L. A. Berckmans was appointed the receiver, and has been disposing of the stock, machinery, and fixtures through the regular channels of trade.

It must be understood that this receivership in no wise grew out of financial embarrassment. The company is entirely solvent, and its integrity has never been questioned. The reason for the receivership was that the business might be closed according to law.

The business of the company will be discontinued after January 1, 1919, in accordance with a decision of a majority of the stockholders, including Messrs. L. A. Berckmans, R. C. Berckmans, and P. J. A. Berckmans, Jr. After that date the business is likely to be carried on by other persons; proper announcement of this will be made in due time.

During the past season we have made every effort to keep the stock up to the high standard which has characterized all the Berckmans products, and the entire nursery has been cared for in our usual efficient fashion. We do not hesitate to say that customers who make up their orders from this price-list will not be disappointed in the quality of the stock which will be furnished.

You are likely to find some good bargains in the list. Particularly do we call your attention to the deciduous trees, the broad-leaved evergreens, and the conifers. In the shrub section you will find many good things, including deutzias, hydrangeas and viburnums, that are of distinct value. The range of sizes shows specimens large enough to give immediate results in landscape work, as well as smaller plants that can be used profitably for "growing on."

We are in a position to make prompt shipments, and have every reason to believe that goods will travel rapidly after being transferred to the express or railroad carriers.

With these words of explanation we feel perfectly justified in asking for your patronage this year, and assure you that both stock and service will be on the same high plane as heretofore.

L. A. BERCKMANS, Receiver for

P. J. BERCKMANS COMPANY AUGUSTA, GEORGIA

September 1, 1918 


\section{TERMS OF SALE}

Our responsibility extends only to persons purchasing direct from us. Dealers purchasing from us sell upon their own responsibility.

If any nursery stock, etc., proves untrue to description under which it is sold, seller shall be liable to the purchaser only and to no greater extent or amount than the purchase price of such nursery stock, etc., and the seller, except for the aforesaid agreed liability and in respect to such purchased nursery stock, etc., gives no warranty, express or implied, as to description, quality, productiveness, or any other matter. P. J. BERCKMANS CO.

PRICES.- This list cancels previous offers, and the prices quoted are net and not subject to discount.

We reserve the right to advance the prices without notice.

Orders for less than 400 trees or plants of a class will be billed at 100 rate; when 400 are ordered, prices will be at rate per 1,$000 ; 40$ at 100 rate; 5 at 10 rate.

Packing Charges.-Boxes will be charged at actual cost of materials. Bales, 25 cents to $\$ 2$, according to size.

Terms of Payment.-Cash with order, or satisfactory reference before shipment; or, if preferred, will ship goods with bill of lading attached to sight draft, through express or bank. On all C. O. D. orders we require 25 per cent of the bill remitted before shipment.

All quotations are for immediate acceptance, subject to stock being sold. No liability to attach to us where frost, drought, or other casualties beyond our control prevent delivery of stock that may be contracted for.

Claims and Liabilities.-We are not liable for delays in transit. Our responsibility ends upon delivery in good order to transportation company. Claims for loss lie between the buyer and the carrier. We will, however, gladly render all aid we can in adjusting these claims.

Shipments.-Please give plain and explicit directions as to route, and manner in which goods are to be forwarded. Give name of express or railroad which you prefer. When no instructions are given, we will ship as we think best for our customers' interests, but without assuming any responsibility.

The Risk and Transportation Charges Are to $\mathrm{Be}$ Borne by Purchaser.

The prices in this list are intended for Nurserymen and Florists only. If this catalogue reaches anyone not entitled to these prices, we would appreciate being advised of the fact so that we can correct our mailing-list. We do not employ agents.

All orders are accepted upon the above conditions. 
Quantity

\section{Fruit Department}

ELAEAGNUS longipes.

$10 \quad 100$

1,000

$25 \quad 5$ to $6 \mathrm{ft}$., bushy........... $\$ 1000$

$60 \quad 4$ to $5 \mathrm{ft}$., bushy............ 800

$25 \quad 3$ to $4 \mathrm{ft}$, bushy............ 500

20

ERIOBOTRYA japonica.

Giant and Palermo, grafted.

253 yrs., from pots........... 400

602 yrs., from pots.......... 300

$80 \quad$ Seedlings, 3 yrs., from pots...... 225

1002 yrs., from pots.......... 150

\section{OLIVE, Picholine.}

$175 \quad 15$ to 18 in., branched, from pots . . $225 \$ 2000$

$325 \quad 12$ to 15 in., branched, from pots. . $175 \quad 1500$

10010 to 12 in., branched, from pots. . $150 \quad 1250$

PEARS, Standard.

5,49022 and 3 yrs., 5 ft. and up, heavy, well-branched..............200 $1500 \$ 12500$

2 yrs., 4 to $5 \mathrm{ft}$., heavy, well-

branched................ $150 \quad 1250 \quad 10000$

\section{Alamo}

Angouleme

Anjou

Archangel

Bartlett

Clapp's

Diel

Flemish Beauty

Garber

Golden Russet
Hawaii
Kieffer
Koonce
La France
Langelier
Lawrence
Le Conte
Lucrative
Magnolia
Marguerite Mikado Philadelphia Seckel Sheldon Smith's Summer Doyenne Superfin Wilder

$10 \quad 100$

6553 yrs., 4 to $5 \mathrm{ft}$., heavy, branched. $\$ 200 \$ 1250$

4652 yrs., 3 to $4 \mathrm{ft}$., branched....... 1501000

Angouleme Anjou Seckel Superfin

PERSIMMONS, Japanese. $\quad 10 \quad 100$

$220 \quad 4$ to $5 \mathrm{ft}$., grafted............ \$2 $50 \$ 1750$

$685 \quad 3$ to $4 \mathrm{ft}$., grafted...........2 $00 \quad 1500$

Costata Hiyakume Triumph

Goshio Miyotan $\quad$ Tsurunoko

Hachiya Tamopan Zengi

PLUM, Cumberland. $\quad 10 \quad 100$

$200 \quad 2$ yrs., 5 to $7 \mathrm{ft}$., $3 / 4$ to 1 in., heavy. $\$ 200 \$ 1750$

3752 yrs., 4 to $5 \mathrm{ft}$., $\frac{\Omega}{16}$ to $5 / 8$ in., stocky. 1501500

\section{POMEGRANATES}

$170 \quad 4$ to $5 \mathrm{ft}$., very bushy . . . . . . $400 \quad 3500$

$360 \quad 3$ to $31 / 2 \mathrm{ft}$., very bushy . . . . . . $300 \quad 2500$

1302 to $3 \mathrm{ft}$., bushy........... $200 \quad 1750$

Paper-shell

Purple-seeded, or Spanish Ruby $\quad$ Sweet

Rhoda

Subacid

Sour

\section{QUINCES}

190 Strong, 3 yrs., budded, 4 to $5 \mathrm{ft}$., $10 \quad 100$ branched.............. \$2 $50 \$ 2000$

385 Strong, 2 yrs., budded, 3 to $4 \mathrm{ft}$.,

branched................2 $200 \quad 1500$

Apple Meech's Prolific Rea's Mammoth

\section{GRAPES}

\section{Native Varieties (2 years)}

$10 \quad 100 \quad 1,000$ 


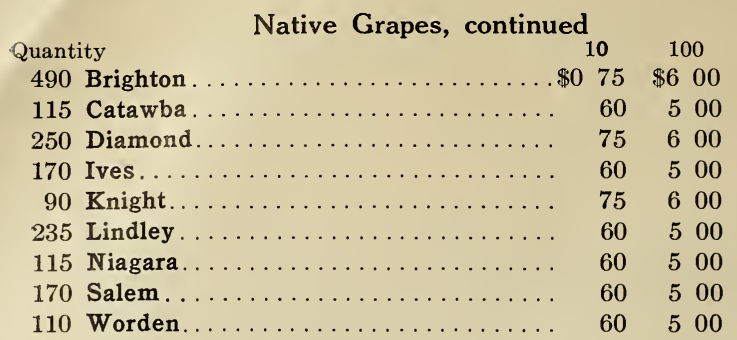

\section{Muscadine Varieties}

Our Muscadine Grapes are especially fine.

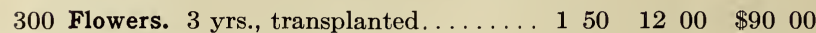

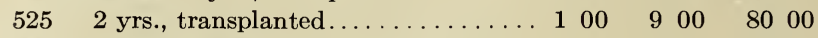

$3,000 \quad 2$ yrs., layers.................. $\quad 6 \quad 600 \quad 5000$

300 James. 2 yrs., layers. . . . . . . . $\quad 6 \quad 600 \quad 5000$

1,350 Thomas. 3 yrs., transplanted....... $150 \quad 1200 \quad 9000$

1652 yrs., transplanted............ $100 \quad 900 \quad 8000$

$2,000 \quad 2$ yrs., layers................ $\quad 6 \quad 600 \quad 5000$

3,500 Scuppernong. 3 yrs., transplanted.... $1150 \quad 1200 \quad 9000$

$1,600 \quad 2$ yrs., transplanted............. $100 \quad 900 \quad 8000$

$5,000 \quad 2$ yrs., layers............... $\quad 6 \quad 60 \quad 5000$

\section{NUT TREES}

CHESTNUT, Large Spanish.

50

45

30

\section{WALNUTS, Black.}

., very heavy, branched... 800

4 to $5 \mathrm{ft}$., heavy, branched...... 500

3 to $4 \mathrm{ft}$., branched........... 250

6 to $8 \mathrm{ft}$., transplanted......... 500

5 to $6 \mathrm{ft}$., transplanted.........4 400

4 to $5 \mathrm{ft}$., transplanted.......... 300

3 to $4 \mathrm{ft}$., transplanted......... $200 \quad 1750$

2 to $3 \mathrm{ft}$., transplanted......... $150 \quad 1250$

English. Good English Walnuts are scarce. We have them.

505 to $6 \mathrm{ft}$., very heavy, transplanted. 600

3904 to $5 \mathrm{ft}$., very heavy, transplanted. 400

425

600

165
3 to $4 \mathrm{ft}$., heavy, transplanted..... 3253000

2 to $3 \mathrm{ft}$., heavy, transplanted..... $250 \quad 2000$

18 to 24 in., heavy, transplanted.. $175 \quad 1500$

\section{Ornamental Department DECIDUOUS SHRUBS}

All of these plants have been given ample space in the rows, and are therefore very stocky and well branched. They must not be conused with those which have not been transplanted and have been grown in crowded rows. We can supply many varieties in carload lots

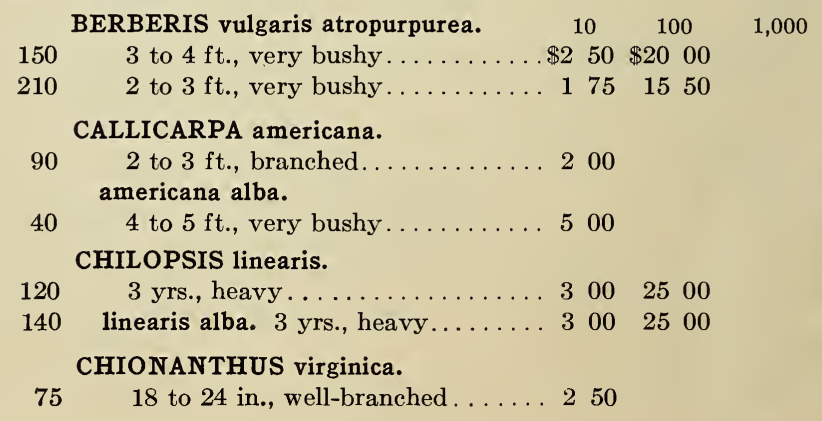


Deciduous Shrubs, continued

\section{CERCIS SILIQUASTRUM}

A new form which originated in our Nursery. A largegrowing shrub or small tree; leaves heart-shaped, and, like those of the other Cercis, assume a yellow tone in autumn. This Judas Tree is the most profuse bloomer we have ever seen, bearing deep lavender flowers four times as large as those of our native Judas Tree. They are produced in large bunches, and, when in full bloom, the tree is a mass of color.

\begin{tabular}{|c|c|c|c|}
\hline Quantity & & 10 & 100 \\
\hline 40 & 6 to $8 \mathrm{ft} .$, extra-heavy, budded. . $\$ 1$ & 000 & \\
\hline 185 & 4 to $6 \mathrm{ft}$., extra-heavy, budded... & 650 & $\$ 6000$ \\
\hline 135 & 3 to $4 \mathrm{ft}$., well-branched, budded. . & 600 & 5000 \\
\hline 75 & 2 to $3 \mathrm{ft}$., well-branched, budded. . & 400 & \\
\hline
\end{tabular}

\section{DEUTZIA gracilis.}

125

275

370

290

60

345

700

1,215

1,010

195

\section{ELEAGNUS longipes.}

in., very bushy........ $300 \quad 2500$

24 to 30 in., very bushy........ $200 \quad 17 \quad 50$

18 to 24 in., very bushy........ $150 \quad 1250$

15 to 18 in., well-branched..... 1251000

gracilis rosea.

2 to $3 \mathrm{ft}$., very bushy......... 200

15 to 18 in., well-branched....... 1251000

scabra crenata, scabra crenata fl.-pl.

alba, scabra crenata fl.-pl. rosea,

and Pride of Rochester.

5 to $6 \mathrm{ft}$., extra heavy . . . . . . . $300 \quad 2000$

4 to $5 \mathrm{ft}$., very heavy......... $150 \quad 12 \quad 50 \$ 11000$

3 to $4 \mathrm{ft}$., heavy.............. $125 \quad 1100 \quad 9000$

2 to $3 \mathrm{ft}$., well-branched........ $100 \quad 800$

\section{(1)}

225

90

255

HIBISCUS SYRIACUS (Althæa). Best

single and double sorts.

4 to $5 \mathrm{ft}$., extra-strong, grafted, and

cuttings, well-branched....... 200

3 to $4 \mathrm{ft}$., strong, grafted and cut-

tings, well-branched........ 175

2 to $3 \mathrm{ft}$., strong, grafted, branched. 125
2 to $3 \mathrm{ft}$., well-branched........ 250 arvifolia.

$\begin{array}{llllll} & & & & & \end{array}$

4 to $5 \mathrm{ft}$., bushy............ $350 \quad 3000$

(o.

EXOCHORDA grandiflora.

3 to $4 \mathrm{ft}$., very heavy. . . . . . . . $200 \quad 17 \quad 50$

.. $150 \quad 501200$

FORSYTHIA, Fortunei and Intermedia.

4 to $5 \mathrm{ft}$., well-branched....... 200

$\begin{array}{llllll} & 25 & 10 & 00\end{array}$

4 to $5 \mathrm{ft}$., well-branched........ $200 \quad 1500$

3 to $4 \mathrm{ft}$., 3 yrs., well-branched... . $150 \quad 1250$

2 to $3 \mathrm{ft}$., 2 yrs., well-branched... $100 \quad 800$
3 to $4 \mathrm{ft}$., bushy............ 500 
Varieties of Hibiscus syriacus, continued

$\begin{array}{ll}\text { amplissimus } & \text { Louis II } \\ \text { Double Pink } & \text { monstrosus } \\ \text { Duchesse de Brabant } & \text { puniceus roseus } \\ \text { Granville } & \text { purpureus semiplenus } \\ \text { Jeanne d'Arc } & \text { ruber flore-pleno } \\ \text { Lady Stanley } & \text { violaceus semiplenus }\end{array}$

Quantity cœlestis, Meehanii, and totus albus. $\begin{array}{ccc}10 & 100 & 1,000\end{array}$

6402 to $3 \mathrm{ft}$., grafted, well-branched. $\$ 175 \$ 1500$

56518 to 24 in., grafted, bushy..... $125 \quad 900$

\section{HYDRANGEA.}

6003 to $4 \mathrm{ft}$, 4 yrs., very heavy, well-

branched..............4 $400 \quad 2500$

$1,200 \quad 24$ to 30 in., 3 yrs., heavy, well-

branched............... $300 \quad 2000$

$550 \quad 18$ to 24 in., 2 yrs., well-branched. . $200 \quad 1750$

$1,100 \quad 12$ to 18 in., branched......... $150 \quad 1200 \$ 10000$
Avalanche
La Lorraine
monstrosa
opuloides otaksa
opuloides cyanoclada
rosea
Souv. de Claire

All the above Hydrangeas have been

grown in regular Hydrangea ground,

and the plants are A No. 1 .

HYPERICUM Moserianum. $\quad 10 \quad 100$

90

3 yrs., heavy.............\$2 00

JASMINUM floridum.

$65 \quad 2$ yrs., very heavy.......... 150 nudiflorum.

$1,000 \quad 2$ to $3 \mathrm{ft}$., very heavy........ $150 \$ 1250$

LAGERSTREMIA indica. Crimson,

Pink, and White.

404 to $5 \mathrm{ft}$., very bushy........ 500

1903 to $4 \mathrm{ft}$., well-branched....... 350

1652 to $3 \mathrm{ft}$., well-branched....... 250 2500

LONICERA

bella, fragrantissima, Morrowii, grandiflora rosea, etc.

$180 \quad 3$ to $4 \mathrm{ft}$., very bushy.........2 $50 \quad 1750$

$675 \quad 2$ to $3 \mathrm{ft}$., bushy............ $150 \quad 1000$

30018 to 24 in., well-branched..... 125800

MERATIA præcox.

$100 \quad 2$ to $3 \mathrm{ft}$, , well-branched.......2 00

\section{PHILADELPHUS}

grandiflorus, laxus, Souv. de Billard, and Lewisii.

5 to $6 \mathrm{ft}$., very heavy......... 300

4 to $5 \mathrm{ft}$., very heavy . . . . . . 200

3 to $4 \mathrm{ft}$., heavy ............ 150

Bouquet Blanc, Conquete, and coronarius.

3 to $4 \mathrm{ft}$., well-branched........ 150

2 to $3 \mathrm{ft}$., well-branched......... 125

18 to 24 in., well-branched....... 100

Lemoinei flore-pleno.

150

12 to 18 in., clumps.......... 125

\section{PUNICA Granatum. Double Red,}

Double Variegated, and Double White.

5 to $6 \mathrm{ft}$., extra heavy, wellbranched............... $500 \quad 4500$

4 to $5 \mathrm{ft}$, extra heavy, well-

branched..............4 $400 \quad 3000$ 3 to $4 \mathrm{ft}$., very heavy, well-branched $\begin{array}{llll}2 & 50 & 20 & 00\end{array}$ 
Quantity

Deciduous Shrubs, continued

PONCIRUS trifoliata.

50022 to $3 \mathrm{ft}$., 3 yrs., strong, well- $10 \quad 100$

branched................\$1 $50 \$ 1000$

750

18 to 24 in., 2 yrs., well-branched. .

500

RHODOTYPOS kerrioides.

1803 to $4 \mathrm{ft}$., very bushy..........2 $200 \quad 1500$

$680 \quad 2$ to $3 \mathrm{ft}$., bushy............. $150 \quad 1250$

$340 \quad 18$ to 24 in., well-branched....... $125 \quad 900$

\section{RHUS Cotinus.}

1006 to $8 \mathrm{ft}$., well-branched....... 500

3255 to $6 \mathrm{ft}$., well-branched........ 350

$140 \quad 4$ to $5 \mathrm{ft}$., well-branched......... 250

$80 \quad 3$ to $4 \mathrm{ft}$., branched............ $150 \quad 1250$

ROSMARINUS officinalis.

160

18 to 24 in., very bushy........ $200 \quad 1500$

\section{SPIRÆA Billardii.}

4 to $5 \mathrm{ft}$., extra heavy, bushy.... $250 \quad 2000$

3 to $4 \mathrm{ft}$., very heavy, bushy..... $150 \quad 1000$

2 to $3 \mathrm{ft}$., heavy, bushy........ $100 \quad 800$ callosa alba.

2 to $3 \mathrm{ft}$., extra-heavy clumps..... 175

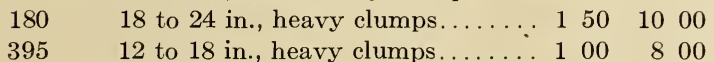

$\begin{array}{rlrrrr}180 & 18 \text { to } 24 \text { in., heavy clumps........ } & 1 & 50 & 10 & 00 \\ 395 & 12 \text { to } 18 \text { in., heavy clumps........ } & 1 & 00 & 8 & 00\end{array}$

380 Fortunei. 2 to $3 \mathrm{ft}$., heavy clumps... $150 \quad 1250$

75 Froebelii. 18 to 24 in., heavy clumps. 125

Reevesiana, Reevesiana flore-pleno and Van Houttei.

1005 to $6 \mathrm{ft}$., extra heavy, bushy.... 350

2154 to $5 \mathrm{ft}$., extra heavy, bushy.... 250

1402 to $3 \mathrm{ft}$., well branched........ $100 \quad 800$

80 STAPHYLEA pinnata. 2 to $3 \mathrm{ft} \ldots \ldots 200$

STYRAX japonica.

704 to $5 \mathrm{ft}$., heavy, well-branched... 400

503 to $4 \mathrm{ft}$., heavy, well-branched... 250

\section{SYMPHORICARPOS vulgaris.}

1002 to $3 \mathrm{ft}$., heavy............ 150

SYRINGA vulgaris. Named sorts, budded.

3 to $4 \mathrm{ft}$., very heavy, well-branched $300 \quad 2500$

2 to $3 \mathrm{ft}$., heavy, well-branched... $1 \quad 75 \quad 1500 \quad \$ 12500$

\section{SINGLE VARIETIES \\ Frau Bertha Dammann \\ Ludwig Spaeth \\ Prof. Stockhardt \\ Emile Lemoine \\ Jeanne d'Arc \\ La Tour d'Auvergne \\ Louis Henri \\ DOUBLE VARIETIES \\ Alphonse Lavalle \\ Mme. Casimir-Perier \\ Matthieu de Dombasle \\ Comte de Jessieu \\ Michel Buchner \\ Comte Horace de Choiseul Pres. Carnot \\ Dr. Masters \\ Pyramidalis \\ Renoncule}

TAMARIX gallica and odessana.

$10 \quad 100$

6 to $8 \mathrm{ft}$., very heavy, well-branched $\$ 3 \quad 00 \$ 2500$

5 to $6 \mathrm{ft}$., very heavy, well-branched $2 \quad 50 \quad 17 \quad 50$

355

4 to $5 \mathrm{ft}$., well-branched........ $150 \quad 1250$

juniperina (plumosa).

6 to $8 \mathrm{ft}$., very heavy, well-branched 350

5 to $6 \mathrm{ft}$., very heavy, well-branched $300 \quad 2500$

4 to $5 \mathrm{ft}$., very heavy, well-branched $250 \quad 1750$ 


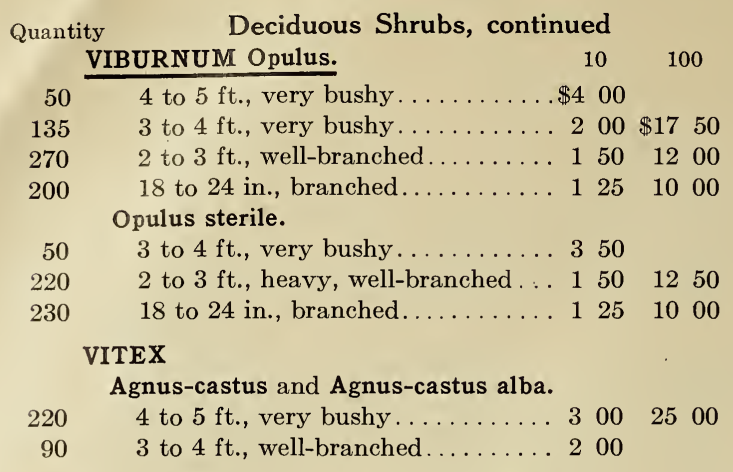

\section{DECIDUOUS TREES}

These trees have been given ample distance in the row, so that the trees could develop properly and symmetrically. We can supply Maples, Hackberry, Texas Umbrella, Sycamore, Poplars, Oaks and Elms in carload lots.

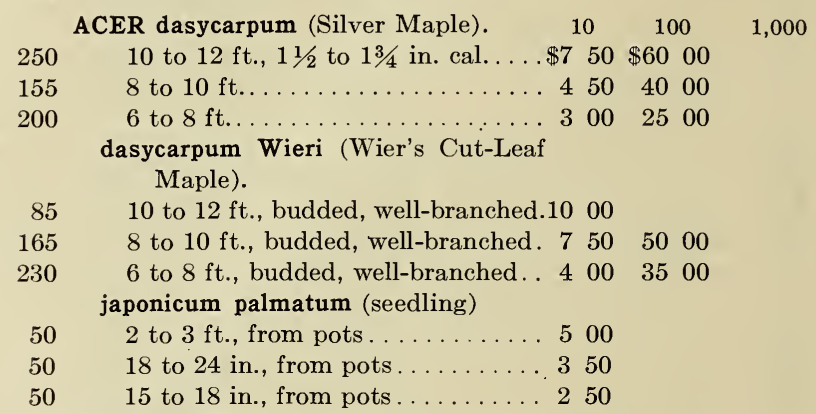

ALEURITES Fordii (Candle-nut or Candleberry Tree).

The walnut-like seed makes an oil which is variously known as Indian walnut oil, Kuqui oil, etc., which is largely used for illuminating purposes. This tree is destined to become very popular in the cotton region, where it can be profitably grown.

$10 \quad 100 \quad 1,000$

10 to $14 \mathrm{ft}$, , very heavy ...... $\$ 1000$

1106 to $8 \mathrm{ft}$., heavy........... 750

204 to $6 \mathrm{ft} . \ldots \ldots \ldots \ldots \ldots \ldots \ldots \ldots$

\section{AMYGDALUS}

Persica (Double-flowering Peach).

5 to $7 \mathrm{ft}$., extra heavy........ $200 \$ 1500$

4 to $5 \mathrm{ft}$., heavy.............. $150 \quad 1250$

200

\section{Chrysanthemum}

75 Double Red

125 Double Pink

200 Double White

\section{APHANANTHE}

aspera (Chinese Hackberry or Nettle Tree).

5010 to $12 \mathrm{ft}$., 1 to $1 \frac{1}{4}$ in. cal., branched................10 00

4008 to $10 \mathrm{ft}$., $3 / 4$ to 1 in. cal., branched. $600 \quad 5000$

3006 to $8 \mathrm{ft}$., branched..........4 $400 \quad 3500$

\section{CELTIS MISSISSIPPIENSIS (Hack-}

berry). The best and straightest

lot we have ever grown.

$550 \quad .14$ to $16 \mathrm{ft}$., 2 to $2 \frac{1}{2}$ in. cal.....20 0017500

95012 to $14 \mathrm{ft}$., $1 \frac{1}{2}$ to 2 in. cal......12 5010000

$800 \quad 10$ to $12 \mathrm{ft}$., $1 \frac{1}{4}$ to $1 \frac{1}{2}$ in. cal.... 7507000

$400 \quad 8$ to $10 \mathrm{ft}$., stocky . . . . . . . . $500 \quad 4000$

12566 to $8 \mathrm{ft} .$, stocky............ $300 \quad 2500$ 


\section{CERCIS}

\section{Deciduous Trees, continued}

canadensis (Red-bud or American

$\begin{array}{clcr}\text { Quantity } & \text { Judas Tree). } & 10 & 100 \\ 50 & 12 \text { to } 16 \mathrm{ft} ., \text { very heavy ....... } \$ 1500 & \\ 235 & 10 \text { to } 12 \mathrm{ft} ., 13 / 4 \text { to } 21 / 4 \text { in. cal. . . } 1200 & \$ 100 & 00 \\ 335 & 8 \text { to } 10 \mathrm{ft} ., 11 / 4 \text { to } 11 / 2 \text { in. cal. . . . } 750 & 6500\end{array}$

1406 to $8 \mathrm{ft}$., 1 to $1 \frac{1}{4}$ in. cal...... $500 \quad 4000$

\section{CORNUS}

FLORIDA (White-flowering Dogwood).

5 to $6 \mathrm{ft}$., extra heavy, well-

branched.............. 600

4 to $5 \mathrm{ft}$., heavy, well-branched . . 500

3 to $4 \mathrm{ft}$., well-branched........ 300

2 to $3 \mathrm{ft}$., branched........... 200

florida flore-pleno.

853 to $4 \mathrm{ft}$., well-branched, budded. . 800

4022 to $3 \mathrm{ft}$., well-branched, budded. . 500

GINKGO biloba (Salisburia).

6 to $8 \mathrm{ft} . \ldots \ldots \ldots \ldots \ldots \ldots \ldots 400$

5 to $6 \mathrm{ft} \ldots \ldots \ldots \ldots \ldots \ldots \ldots \ldots \ldots$

4 to $5 \mathrm{ft} . \ldots \ldots \ldots \ldots \ldots \ldots \ldots \ldots$

\section{KOELEUTERIA}

paniculata (Golden Rain Tree).

40

40

385

\section{LIQUIDAMBAR}

Styraciflua (Sweet Gum).

12 to $16 \mathrm{ft}$., $2 \frac{1}{2}$ to 3 in. cal., very

heavy.................. 50

10 to $12 \mathrm{ft}$., 2 to $2 \frac{1}{2}$ in. cal., very heavy................. 1500

8 to $10 \mathrm{ft}$., $1 \frac{1}{2}$ to 2 in. cal., wellbranched............... 900

130

6 to $8 \mathrm{ft}$., 1 to $1 \frac{1}{4}$ in. cal., branched. 800

5 to $6 \mathrm{ft}$, stocky.............. 500

\section{LIRIODENDRON}

Tulipifera (Tulip Poplar).

10 to $12 \mathrm{ft}$., $13 / 4$ to 2 in. cal. .... $800 \quad 7000$

8 to $10 \mathrm{ft}$., $1 \frac{1 / 4}{4}$ to $13 / 4$ in. cal..... $600 \quad 5000$

200

6 to $8 \mathrm{ft} ., 1$ to $1 \frac{1}{4} \mathrm{in}$. cal.......4 50

\section{MAGNOLIA}

OBOVATA (purpurea). Home-grown. Very thrifty and well-grown plants.

to $6 \mathrm{ft}$., very bushy specimens. . 2000

4 to $5 \mathrm{ft}$., very bushy specimens...10 $00 \quad 8000$

3 to $4 \mathrm{ft}$., well-branched........6 $00 \quad 5000$

2 to $3 \mathrm{ft}$., well-branched........ $400 \quad 3500$

18 to 24 in., branched.......... 300 2500

\section{Soulangeana.}

4 to $4 \frac{1}{2} \mathrm{ft}$., heavy, imported. . . . 2500

3 to $4 \mathrm{ft}$, heavy, imported......20 00

2 to $3 \mathrm{ft}$., heavy, home-grown layers. 750

18 to 24 in., home-grown layers... 300

Soulangeana nigra. Home-grown.

5 to $6 \mathrm{ft}$., heavy.............25 00

4 to $5 \mathrm{ft}$., heavy............. 1250

3 to $4 \mathrm{ft}$., heavy.............. 1000

2 to $3 \mathrm{ft} ., 2$ yrs............. 500 


Deciduous Trees, continued
MELIA
Azedarach aurea (Golden Leaf China $10 \quad 100$

\section{PLATANUS OCCIDENTALIS (Ameri-} can Sycamore). These are beautiful, straight, well-developed trees. 14 to $16 \mathrm{ft}, 2 \frac{1}{2}$ to $23 / 4$ in. cal. . . . 175014000 12 to $14 \mathrm{ft}$., 2 to $2 \frac{1}{2}$ in. cal. . . . . 125011000 10 to $12 \mathrm{ft}$, $1 \frac{1}{4}$ to $1 \frac{1}{2}$ in. cal.... $600 \quad 5000$ 8 to $10 \mathrm{ft}$., well-branched, heavy . . 3503000 6 to $8 \mathrm{ft}$., well-branched........2 $200 \quad 1750$

\section{POPULUS}

deltoides monilifera (Carolina Poplar).

\section{PRUNUS}

\section{AVIUM FLORE - PLENO ALBA}

(Japanese Flowering Cherry).

QUERCUS alba (White Oak). nigra italica (Lombardy Poplar).

14 to $16 \mathrm{ft.}, 2$ to $2 \frac{1}{4}$ in. cal. . . . . . 1250 Simonii (Chinese Poplar).

14 to $16 \mathrm{ft.}, 21 / 2$ to 3 in. cal. . . . . 1250 Mume. 2 yrs., heavy.......... 300 subhirtella pendula rosea (Weeping

Flowering Cherry).

2-yr. heads . . . . . . . . . . . . . 1000

6 to $8 \mathrm{ft} ., 3 / 4$ to 1 in. cal. ....... 1000

NIGRA (Water Oak).

14 to $16 \mathrm{ft}$., $2 \frac{1}{2}$ to $3 \mathrm{in}$. cal. . . . .50 00 12 to $14 \mathrm{ft}$., 2 to $2 \frac{1}{2}$ in. cal. . . . . .35 00 8 to $10 \mathrm{ft}$., 1 to $1 \frac{1 / 4}{4}$ in cal........ 800

14 to $16 \mathrm{ft}$., $2 \frac{1}{2}$ to $3 \mathrm{in}$. cal. . . . $1250 \quad 9000$ to $14 \mathrm{ft} ., 13 / 4$ to 2 in. cal. . . . . 7506000 10 to $12 \mathrm{ft} ., 1 \frac{1}{2}$ to $13 / 4$ in. cal.... $500 \quad 3500$ 8 to $10 \mathrm{ft} ., 11 / 4$ in. cal. .......... $250 \quad 1750$ 6 to $8 \mathrm{ft} \ldots \ldots \ldots \ldots \ldots \ldots \ldots \ldots 150 \quad 1200$ 10 to $12 \mathrm{ft} ., 1 \frac{1}{2}$ to $13 / 4$ in. cal.... 5003500 8 to $10 \mathrm{ft} ., 1 \frac{1}{4}$ to $1 \frac{1 / 2}{2}$ in. cal..... 2 $250 \quad 1750$ 6 to $8 \mathrm{ft}, 1$ in. cal. ........... $150 \quad 1250$ 12 to $14 \mathrm{ft}$, $1 \frac{1 / 2}{2}$ to 2 in. cal. . . . . $1000 \quad 8000$ 10 to $12 \mathrm{ft} ., 1 \frac{1}{4}$ to $1 \frac{1}{2}$ in. cal.... $500 \quad 3500$ 8 to $10 \mathrm{ft} ., 1 \frac{1}{4}$ in. cal. . . . . . . . $250 \quad 1750$ 6 to $8 \mathrm{ft} ., 1$ in. cal. . . . . . . . . $150 \quad 1250$

6 to $7 \mathrm{ft}$., heavy, well-branched . . $750 \quad 6000$

5 to $6 \mathrm{ft}$., heavy, well-branched ... $500 \quad 3500$

4 to $5 \mathrm{ft}$., branched........... $300 \quad 2500$

3 to $4 \mathrm{ft}$., branched............ 25002000 cerasifera Pissardii. 5 to $7 \mathrm{ft} \ldots \ldots .300 \quad 2500$

5 to $6 \mathrm{ft} \ldots \ldots \ldots \ldots \ldots \ldots \ldots \ldots 750 \quad 5000$ 6 to $8 \mathrm{ft} ., 3 / 4$ to 1 in. cal. . . . . . $600 \quad 5000$

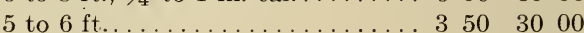




\section{Quantity Deciduous Trees, continued}

QUERCUS PALUSTRIS (Pin Oak). 10

$100 \quad 1,000$

$25 \quad 12$ to $15 \mathrm{ft}$., 2 to $2 \frac{1}{2} \mathrm{in}$. cal.... $\$ 2500$

$40 \quad 10$ to $12 \mathrm{ft}$., $13 / 4$ to $2 \mathrm{in}$. cal. .....17 50

8308 to $10 \mathrm{ft}$., $1 \frac{1 / 2}{2}$ to $1 \frac{3}{4}$ in. cal..... $1500 \$ 12000$

$2,000 \quad 6$ to $8 \mathrm{ft}$., $3 / 4$ to $1 \mathrm{in}$. cal........ $800 \quad 6000$

$650 \quad 5$ to $6 \mathrm{ft} \ldots \ldots \ldots \ldots \ldots \ldots \ldots 600 \%$

\section{PHELLOS.}

1308 to $10 \mathrm{ft}$., $1 \frac{1 / 4}{4}$ to $1 \frac{1}{2}$ in, cal......10 $00 \quad 8000$

4806 to $8 \mathrm{ft}$., 1 to $11 / 4 \mathrm{in.} \mathrm{cal.} \mathrm{......} 750 \quad 6000$

$575 \quad 5$ to $6 \mathrm{ft}$., well-branched........6 $600 \quad 4000$ rubra (Red Oak).

258 to $10 \mathrm{ft}$., 1 to $1 \frac{1}{4}$ in. cal. ...... 1000

$100 \quad 6$ to $8 \mathrm{ft}, 3 / 4$ to 1 in. cal. ..... 750

$75 \quad 5$ to $6 \mathrm{ft} \ldots \ldots \ldots \ldots \ldots \ldots 60$

6000

\section{SALIX babylonica.}

$50 \quad 8$ to $10 \mathrm{ft}$., very heavy........ 350

12566 to $8 \mathrm{ft}$., very heavy.......... 200

955 to $6 \mathrm{ft}$., well-branched....... 150

SPONDIAS lutea (Poupartia).

$55 \quad 10$ to $12 \mathrm{ft}$., very heavy . . . . . 1000

208 to $10 \mathrm{ft}$., very heavy........8 800

$20 \quad 6$ to $8 \mathrm{ft}$., very heavy.........6 60

\section{TAXODIUM distichum.}

208 to $10 \mathrm{ft}$., very heavy, trans-

planted...............20 00

306 to $8 \mathrm{ft}$., very heavy, transplanted.10 00

255 to $6 \mathrm{ft}$., very heavy, transplanted. 600

\section{TILIA americana.}

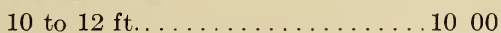

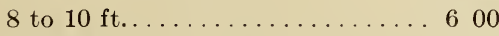

6 to $8 \mathrm{ft} \ldots \ldots \ldots \ldots \ldots \ldots \ldots$

\section{ULMUS}

AMERICANA (American White Elm).

6012 to $14 \mathrm{ft}$., $13 / 4$ to $2 \mathrm{in.} \mathrm{cal.....20} 00$

36510 to $12 \mathrm{ft} ., 1 \frac{1}{4}$ to $1 \frac{1}{2} \mathrm{in}$. cal. . . 750

$1,395 \quad 8$ to $10 \mathrm{ft} .1$ to $1 \frac{1}{4} \mathrm{in}$. cal. ..... 500

575
6 to $8 \mathrm{ft}$., $3 / 4$ to $1 \mathrm{in}$. cal.
300
2500

6000

$40 \quad 00 \$ 350 \quad 00$

\section{BROAD-LEAVED EVERGREEN TREES AND SHRUBS}

All of our Broad-leaved Evergreens are grown most carefully. Those which are grown in open ground have been several times transplanted, and when shipped are lifted with a ball of earth about the roots, which is wrapped in burlap.

All plants which are grown in pots have been several times repotted and plunged in open frames where they are given ample space. Our plants are, therefore, stocky and well-rooted.

Unless otherwise noted, all plants are from open ground. In this locality we are particularly fortunate in being able to grow such a large number of desirable broad-leaved evergreen trees and shrubs. We grow many kinds that are not hardy in the far North, also bring to perfection a large proportion of the hardy northern evergreens. The great variety of soils in our nursery permits us to grow this extensive collection.

\section{ABELIA grandiflora.}

$50 \quad 2$ to $3 \mathrm{ft}$., strong plants from open $10 \quad 100 \quad 1,000$ ground.............\$5 00

20018 to 24 in., strong plants from open ground................ $300 \$ 2500$

$275 \quad 12$ to 18 in., strong plants from open ground............... $250 \quad 1750$ 


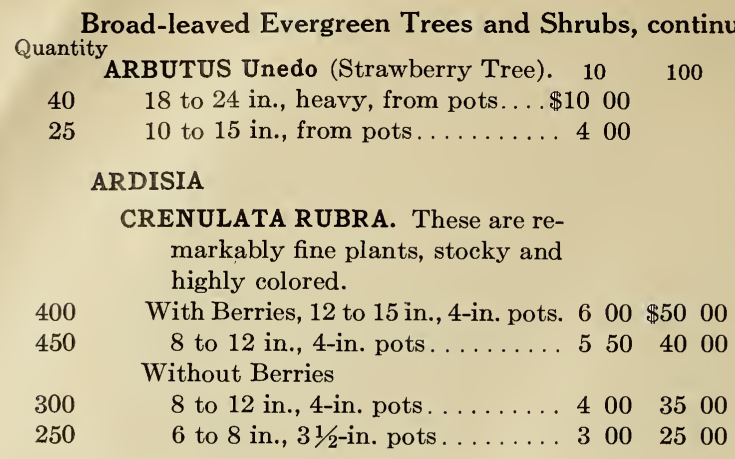

\section{AUCUBA japonica.}

2 to $3 \mathrm{ft}$., branched............6 600

18 to 24 in., branched.......... $500 \quad 4500$

12 to 15 in., branched........... $350 \quad 3000$

10 to 12 in., partly branched .... $275 \quad 2500$

japonica aureo-maculata.

18 to 24 in., branched..........6 600

12 to 18 in., partly branched.... $3 \quad 00 \quad 27 \quad 50$

AZALEA amœna. Home-grown.

30

100

250

100

600

250

\section{AZALEA INDICA. Home-grown.}

All of the Indian Azaleas offered are home-grown, vigorous, and healthy. We offer about fifty fine varieties. The colors are in all shades of crimson, scarlet, purple, pink, and with exquisitely variegated mottlings, stripes, and blotches. We offer single varieties only. All of our plants are grown in summer in open ground, under partial shade, and lifted in October, when they are thoroughly matured. All plants, therefore, have a fine ball of earth about the roots and are shipped without losing a bud or leaf. $\begin{array}{llll}10 & 100 & 1,000\end{array}$ 12 to 15 in., well-branched..... \$4 $50 \$ 4000$ 8 to 12 in., branched........... $300 \quad 27 \quad 50 \$ 250 \quad 00$ 6 to 8 in., branched............. $250 \quad 50 \quad 2000 \quad 175 \quad 00$
4 to 6 in., branched
200
$1750 \quad 15000$

\section{AZALEA}

KAEMPFERI (Japanese Azalea).

12 to 15 in., well-branched, well set

with buds..............6 $600 \quad 5000$

1458 to 12 in., well-branched ...... $450 \quad 3500$

9006 to 8 in., branched..........2 $50 \quad 2000$

\section{BERBERIS Sargentiana.}

12 to 15 in

\section{BUXUS balearica.}

15 to 18 in., very bushy....... 800

SUFFRUTICOSA (Dwarf Box).

3 to 4 in., bushy.............

\section{CALLISTEMON}

lanceolatus (Bottle-Brush).

From 4-in. pots........... 500 
Broad-leaved Evergreen Trees and Shrubs, continued

CAMELLIA

$\begin{array}{lllll}\text { Quantity JAPONICA. Our own growing. } & 10 & 100 & 1,000\end{array}$

$500 \quad 18$ to 24 in., not branched. . . . .\$10 $00 \$ 8000$

$1,000 \quad 15$ to 18 in., not branched...... $800 \quad 6000$

$100 \quad 12$ to 15 in., branched.........6 $600 \quad 5000$

$100 \quad 12$ to 15 in., not branched....... $375 \quad 3500$

$1,800 \quad 8$ to 12 in., not branched, from pots. $300 \quad 2750$

2,0006 to 8 in., not branched, from pots. . $200 \quad 1750$

\section{CINNAMOMUM}

CAMPHORA (Camphor Tree).

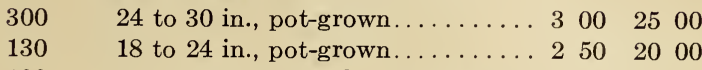

10030 to 36 in., stocky, field-grown, transplanted............ 300

40024 to 30 in., stocky, field-grown, transplanted..............2 $250 \quad 2000$

2,00018 to 24 in., stocky, field-grown, transplanted.............2 $200 \quad 1750$

CITRANGE. Grafted on Citrus trifoliata. Morton, Rusk, and Willet.

4 to $5 \mathrm{ft}$., well-branched........ 500

3 to $4 \mathrm{ft}$., well-branched........ 400

\section{CLEYERA japonica.}

$45 \quad 15$ to 18 in., from 4 -in. pots.... 500

$150 \quad 12$ to 15 in., from 3 -in. pots..... 350

ELÆAGNUS Fruitlandii.

15 to 18 in., very bushy........6 00

12 to 15 in., heavy, well-branched. 500

8 to 12 in., from pots........ 300

40 macrophylla. 12 to $18 \mathrm{in}$., from pots. 500 pungens Simoni.

$100 \quad 18$ to 24 in., grafted, very bushy...10 00

$40 \quad 15$ to 18 in., grafted, well-branched 600

\section{ERIOBOTRYA}

japonica (Japan Medlar). Giant and

Palermo, grafted.

3 yrs., from pots. . . . . . . . . 400

2 yrs., from pots.......... 300

Seedlings, 3 yrs., from pots...... 225

2 yrs., from pots......... 150

\section{ESCALLONIA montevidensis.}

\section{7}

\section{GARDENIA}

florida and Fortunei (Cape Jasmine).

400

ILEX Aquifolium (English or European

$$
\text { Holly). }
$$

15 to 18 in., branched, from pots.. $2 \quad 75 \quad 2250$ 12 to 15 in., branched, from pots. . $250 \quad 2000$ radicans (Dwarf Cape Jasmine).

12 to 15 in., bushy, from 4 -in. pots. 300 8 to 12 in., bushy, from 4 -in. pots. 250

18 to 24 in., well-branched. . . . 600 12 to 18 in., strong, well-branched. 500 opaca.

3 to $4 \mathrm{ft}$., branched............10 $00 \quad 8000$

2 to $3 \mathrm{ft}$., branched.......... 500

12 to 18 in., from pots......... $350 \quad 3000$

8 to 12 in., from pots......... 250

vomitoria (Cassine).

18 to 24 in., very bushy, from open

ground................... $300 \quad 2500$ 15 to 18 in., from pots........ $300 \quad 2500$ 
Broad-leaved Evergreen Trees and Shrubs, continued Quantity

ILLICIUM anisatum (Anise Tree).

1752 to $3 \mathrm{ft}$., well-branched, from open $\begin{array}{llll}10 & 100 & 1,000\end{array}$ ground................\$5 $00 \$ 4500$

20018 to $24 \mathrm{in}$., branched, from pots. . $300 \quad 2750$

\section{LAUROCERASUS}

CAROLINIANA (Carolina Cherry).

$1,500 \quad 3$ to $4 \mathrm{ft}$., very bushy, from open ground............... $500 \quad 3500$

$2,000 \quad 2$ to $3 \mathrm{ft}$., very bushy, from open ground............... $300 \quad 2500$

18 to 24 in., bushy, from open ground............... $175 \quad 1500$

officinalis (English or Cherry Laurel), Bertinii, caucasica, colchica, rotundifolia and versaillensis.

3 to $4 \mathrm{ft}$., very bushy.........20 00 30 to 36 in., bushy . . . . . . . . $1000 \quad 8000$ 24 to 30 in., well-branched. . . . $800 \quad 7000$ 18 to 24 in., well-branched . . . . $600 \quad 5000$ 15 to 18 in., branched......... $400 \quad 3500$

\section{LAURUS}

nobilis (Bay Tree or Spice Laurel).

18 to 24 in., strong, well-branched,

from open ground ......... 500

15 to 18 in., well-branched, from

open ground.............. $350 \quad 3000$

12 to 15 in., branched, from pots. . 2752500 regalis.

12 to 15 in., branched, from pots.. $275 \quad 2500$

\section{LIGUSTRUM}

JAPONICUM (Japanese Privet).

6 to $7 \mathrm{ft}$., extra-heavy, bushy speci-

mens................50 00

5 to $6 \mathrm{ft}$., extra-heavy, bushy specimens.................... 3000

4 to $5 \mathrm{ft}$., extra-heavy, bushy . . .20 00

3 to $4 \mathrm{ft}$., extra-heavy, bushy.... $10 \quad 00 \quad 8000$

2 to $3 \mathrm{ft}$., well-branched........ $500 \quad 4000$

18 to 24 in., well-branched . . . . . $300 \quad 2500$ japonicum excelsum superbum.

3 to $4 \mathrm{ft}$., grafted, very bushy..... 1500

2 to $3 \mathrm{ft}$., grafted, well-branched. $600 \quad 5000$

18 to 24 in., grafted, well-branched $400 \quad 3500$ lucidum. 15 to 18 in., well-branched. 500 japonicum macrophyllum.

12 to 15 in., branched......... 500

\section{JAPONICUM MARGINATUM} AUREUM.

4 to $5 \mathrm{ft}$., grafted, very bushy specimens................20 00

3 to $4 \mathrm{ft}$., grafted, very bushy....15 $00100 \quad 00$ 2 to $3 \mathrm{ft}$., grafted, well-branched. . $600 \quad 5000$ 18 to 24 in., grafted, well-branched $400 \quad 3500$ nepalense.

24 to 30 in., very bushy........10 $00 \quad 8000$ 18 to 24 in., very bushy........ $500 \quad 4000$ 15 to 18 in., very bushy....... $400 \quad 3000$

\section{MAGNOLIA GRANDIFLORA.}

4 to $5 \mathrm{ft}$., well-branched, from open

ground.............. $800 \quad 7000$ 
Broad-leaved Evergreen Trees and Shrubs, continued

\section{Magnolia grandiflora, continued}

Quantity

3 to $4 \mathrm{ft}$., well-branched, from open $10 \quad 100$ ground.................\$6 $00 \$ 5000$

2 to $3 \mathrm{ft}$., branched, from open ground............... $400 \quad 3500$

300

600

125

\section{MAHONIA}

Aquifolium (Holly-leaved Ashberry).

12 to 18 in., branched.......... 200 japonica (Berberis japonica).

12 to 18 in., from open ground... 300

8 to 10 in., from pots........ 175

MICHELIA fuscata (Banana Shrub).

36 to 40 in., very bushy, from open ground................. 3000

30 to 36 in., very bushy, from open ground................25 00

24 to 30 in., very bushy, from open ground................. 1500

18 to 24 in., very bushy, from open ground.............. 1000

15 to 18 in., well-branched, from pots............... $500 \quad 4000$ 12 to 15 in., branched, from pots. . $300 \quad 2500$ 10 to 12 in., branched, from pots. . $250 \quad 2000$ 8 to 10 in., branched, from pots... $175 \quad 1500$

\section{NERIUM (Oleander).}

3 to $4 \mathrm{ft}$., heavy, well-branched, from open ground .........6 60

30 to 36 in., well-branched, from open ground.............. $500 \quad 4000$

15 to 20 in., from pots........ $250 \quad 2000$ Cardinal. Single; crimson.

Mme. Peyre. Very double; triple corolla; pale flesh. Prof. Parlatorre. Pink; double corolla.

Semi-double White.

Single White.

Splendens. Double; deep pink.

\section{OSMANTHUS}

Fortunei (Holly-leaved Tea Olive).

12 to 15 in., well-branched, from pots................ $350 \quad 3000$

10 to $12 \mathrm{in.}$, branched, from pots. . $300 \quad 2500$ fragrans (Tea Olive).

\section{PHOTINIA serrulata.}

24 to 30 in., very bushy, from open ground............... 1500 15 to 18 in., from pots........ $500 \quad 4000$ 12 to 15 in., from pots........ $300 \quad 2750$
8 to 10 in., from pots. $\begin{array}{ll}27 & 50 \\ 17 & 50\end{array}$

2 to $3 \mathrm{ft}$., heavy, budded.

\section{PITTOSPORUM Tobira.}

3 to $4 \mathrm{ft}$., very bushy, from open ground..............20 00

30 to 36 in., bushy, from open ground............... 1500 24 to 30 in., bushy, from open ground................ 1000

18 to 24 in., bushy, from open ground.............. 600 
Broad-leaved Evergreen Trees and Shrubs, continued Pittosporum Tobira, continued

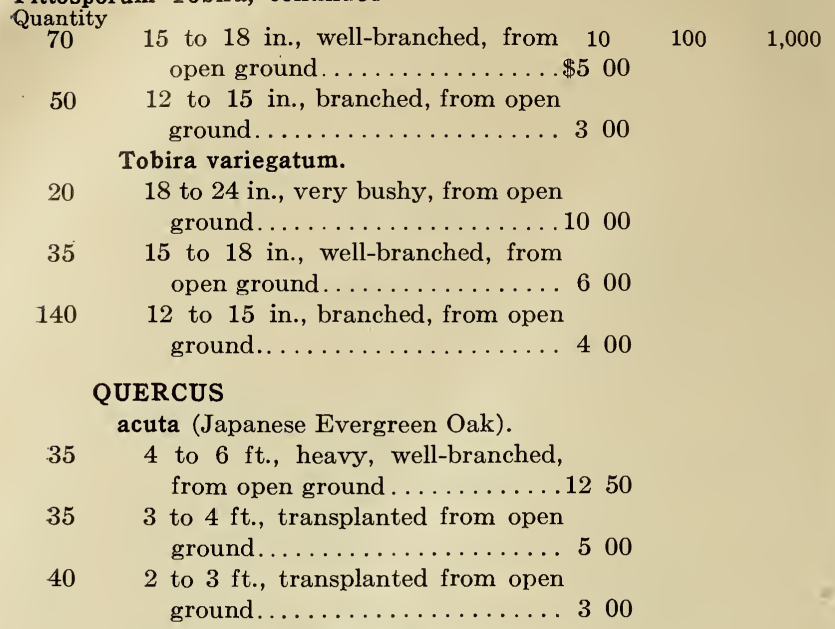

\section{LAURIFOLIA DARLINGTONII (Dar-} lington Oak). Transplanted. 10 to $12 \mathrm{ft}$., $1 \frac{1}{4}$ to $1 \frac{1}{2}$ in. cal. . . . 1000 8 to $10 \mathrm{ft}$., 1 to $1 \frac{1 / 4}{4}$ in. cal. ...... $600 \$ 5000$ 6 to $8 \mathrm{ft}$, $3 / 4$ to $1 \mathrm{in}$. cal........4 4003500

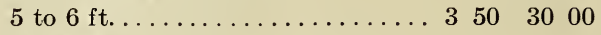
virginiana (Live Oak). Transplanted.

6 to $8 \mathrm{ft}$., $3 / 4$ to 1 in. cal. .......6 600

5 to $6 \mathrm{ft}$., branched.......... 400

\section{TRACHYCARPUS}

Fortunei (Chamærops Fortunei).

18 to 24 in., extra heavy ....... 750

15 to 18 in., strong........... 50004000

12 to 15 in., strong............ $350 \quad 3000$

\section{VIBURNUM odoratissimum.}

140

18 to 24 in., well-branched, from

open ground............ 600

15 to 18 in., from pots and open

ground................ 350

suspensum. 12 to 15 in., from pots.. 350 Tinus (Laurustinus).

20 to 24 in., from pots. . . . . . 600

15 to 20 in., from pots........ 450

12 to 15 in., from pots........ 300

8 to 12 in., from pots........ 250

\section{YUCCA filamentosa.}

4 and 5 yrs., strong, transplanted.. 250 gloriosa. 4 yrs., strong, transplanted. 500

\section{CLIMBERS}

\section{ACTINIDIA chinensis.}

\section{AKEBIA quinata.}

3 yrs., from open ground....... 150

2 yrs., from pots........... 125

lobata. From 3 -in. pots........ 150

\section{AMPELOPSIS Henryana.}

$\begin{array}{llllll}315 & 3 & \text { yrs., extra strong, field-grown. . } 175 & 15 & 75\end{array}$ quinquefolia (Virginia Creeper). 


\section{Quantity Climbers, continued}

BIGNONIA capreolata (Cross-Vine).

2003 yrs., strong clumps, from open $10 \quad 100 \quad 1,000$ ground................. \$2 $25 \$ 2000$

2402 yrs., strong, from 3-in. pots.... $150 \quad 1250$ hybrida. This variety is hardy in Washington.

4304 yrs., extra heavy, grafted..... $4 \quad 00 \quad 3000$

$180 \quad 3$ yrs., extra heavy, grafted...... $275 \quad 2500$

ELEAGNUS pungens reflexa.

254 to $5 \mathrm{ft}$., very bushy specimens from open ground......... 1500

1752 to $3 \mathrm{ft}$., heavy, well-branched, from open ground.......... $5 \quad 00 \quad 45 \quad 00$

5518 to 24 in., strong, from open ground.............. 300

$190 \quad 15$ to 18 in., strong, from open ground and pots......... $250 \quad 2000$

EUONYMUS radicans.

60024 to 30 in., extra-heavy, fieldgrown clumps............. $300 \quad 2500$ 18 to 24 in., strong, field-grown clumps...............2 $50 \quad 2250$

12 to 18 in., strong, field-grown clumps.............. $200 \quad 1500$ radicans variegata.

18 to 24 in., extra-heavy, fieldgrown clumps........... $250 \quad 22 \quad 50$

12 to 18 in., strong, field-grown clumps...............2 $200 \quad 1500$

\section{GELSEMIUM}

sempervirens flore-pleno (Double Yellow Jasmine).

1453 yrs., extra-strong clumps......5 00

1252 yrs., strong plants ......... 250

HEDERA helix (English Ivy).

$650 \begin{aligned} & \text { H-in. pots, strong............. } 150 \\ & 60\end{aligned}$

\section{JASMINUM PRIMULINUM (New} Chinese Jasmine).

$500 \quad 4$ to $5 \mathrm{ft}$., extra-strong clumps.... $250 \quad 2000$

$400 \quad 3$ to $4 \mathrm{ft}$., strong clumps ....... $200 \quad 1500$

\section{KADSURA japonica.}

175 From 3 - and $3 \frac{1}{2}$-in. pots, strong. . $275 \quad 2500$

LONICERA Heckrottii.

$150 \quad 3$ yrs., strong............. $200 \quad 1500$

900 japonica (Halliana). 3 yrs., strong... $150 \quad 1250$

\section{TRACHELOSPERMUM}

jasminoides (Rhynchospermum jasminoides).

From $3 \frac{1}{2}$-in. pots, strong. . . . . $200 \quad 1750$

\section{VINCA}

major (Periwinkle, or Trailing Myrtle).

1,500 Strong clumps from open ground. . 100 minor.

Strong clumps from open ground. . 100

\section{WISTERIA chinensis.}

1253 yrs., heavy, grafted......... 300

2 yrs., heavy, grafted......... 200

120 chinensis alba. 2 yrs., heavy, grafted. 200 chinensis flore-pleno.

2 yrs., heavy, grafted......... 200 


\section{GRASSES}

CORTADERIA (Pampas Grass).

\section{Quantity ARGENTEA.}

700 Extra-heavy clumps, 18 in. diam., $10 \quad 100 \quad 1,000$ from open ground ........ \$15 $00 \$ 12500$

50 Extra-heavy clumps, 12 to $15 \mathrm{in}$. diam., from open ground. . . . 1250

200 Heavy clumps, 8 in. diam., from open ground............ $500 \quad 4500$

Roi des Roses.

35 Extra-heavy clumps, 18 in. diam., from open ground . . ...... 1500

Extra-heavy clumps, 12 to 15 in. diam., from open ground..... . 500

\section{MISCANTHUS (Eulalia).}

SINENSIS GRACILLIMUS.

Extra-heavy clumps, 18 in. diam.,

from open ground .......... 1500

Extra-heavy clumps, 12 to 15 in. diam., from open ground......12 50 sinensis variegatus.

Extra-heavy clumps, 12 to 15 in. diam., from open ground.....12 50 sinensis zebrinus.

Extra-heavy clumps, 18 in. diam., from open ground.........1500

Extra-heavy clumps, 12 to 15 in. diam., from open ground......12 50

\section{CONIFEROUS EVERGREENS}

It is an undisputed fact that we grow the largest and most varied stock of coniferous evergreens in the southern states, and especially do we give attention to such varieties as are best adapted to this warmer climate. We also grow large quantities of hardy varieties of Chamæcyparis, Cupressus, Juniperus, Pines, and Thuyas adapted to the northern parts of the country. All of our conifers have been several times transplanted. All plants are shipped with a ball of earth about the roots which is wrapped in burlap.

\section{CEDRUS}

ATLANTICA (Mount Atlas Cedar).

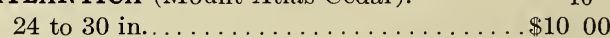

18 to 24 in..................... $750 \$ 6000$

15 to 18 in.................... $500 \quad 4000$

Deodara (Himalayan Cedar).

18 to 24 in...................... 600

15 to 18 in.................. 500

Libani (Cedar of Lebanon.)

15 to 18 in................... 750

12 to 15 in................... 500

CEPHALOTAXUS drupacea.

140

12 to 18 in. spread, from pots.

\section{Fortunei.}

3 to $4 \mathrm{ft}$., extra heavy...............1500

30 to 36 in., heavy . . . . . . . . . . . 800

24 to 30 in., heavy . . . . . . . . . . . . 500

18 to 24 in..................... 350

Harringtonia.

15 to 18 in., branched............... 500

12 to 15 in., branched.............. $350 \quad 3000$

Harringtonia fastigiata.

24 to 30 in., very heavy............ 750

18 to 24 in., well-branched. . . . . . . . 400

15 to 18 in., well-branched . . . . . . . . . 3002500

12 to 15 in....................... $250 \quad 2000$ 
Coniferous Evergreens, continued

CHAM ECYPARIS

Quantity Lawsoniana (Cupressus Lawsoniana). $\quad 10 \quad 100$

$50 \quad 5$ to $6 \mathrm{ft}$., very compact...........\$30 00

1404 to $5 \mathrm{ft}$., very compact............20 $00 \$ 17500$

1803 to $4 \mathrm{ft}$., very compact............. $12 \quad 50 \quad 100 \quad 00$

$60 \quad 2$ to $3 \mathrm{ft}$., compact............. 500

\section{PISIFERA.}

4 to $5 \mathrm{ft}$., very compact...................... 00

3 to $4 \mathrm{ft}$., very compact.............25 00

30 to 36 in., very compact............ 1500

18 to 24 in., compact.............. 600

15 to 18 in., compact.............. 500

12 to 15 in., compact. . . . . . . . . . 300

10 to 12 in., compact............... 250

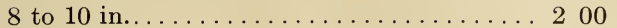

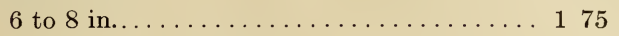

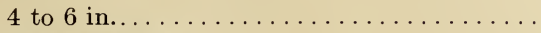

pisifera argentea.

30 to 36 in., very compact, sheared......50 00 24 to 30 in., very compact, sheared.......20 00 18 to 24 in., very compact, sheared...... 1500 15 to 18 in., very compact, sheared....... 900 12 to 15 in., compact, sheared..........6 600

10 to 12 in., compact, sheared......... 500

\section{PISIFERA AUREA.}

4 to $5 \mathrm{ft}$., very compact, sheared .......40 00 3 to $4 \mathrm{ft}$., very compact, sheared........25 00 2 to $3 \mathrm{ft}$, very compact, sheared......... 1500 18 to 24 in., very compact, sheared....... 800 15 to 18 in., very compact, sheared...... 500 12 to 15 in., compact. . . . . . . . . . . 400 10 to 12 in., compact.............. 250 8 to 10 in., compact............... 200

6 to 8 in., compact................ 175 4000

\section{pisifera filifera.}

6 to $7 \mathrm{ft}$., compact, sheared specimens. . . .50 00 5 to $6 \mathrm{ft}$., compact, sheared specimens. . . . 4000 3 to $4 \mathrm{ft}$., compact, sheared specimens. . . .25 00 pisifera filifera aurea.

3 to $4 \mathrm{ft}$, very compact...............25 00 24 to 30 in., very compact.......................... 00 18 to 24 in., compact............... 1250

15 to 18 in., compact. . ............. 1000 pisifera filifera aurea Fulleri.

5 to $6 \mathrm{ft}$., compact specimens.........4500

4 to $5 \mathrm{ft}$, compact specimens............. 3000

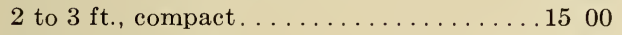

18 to 24 in., compact. . . . . . . . . . . 1000

15 to 18 in., compact.............. 600

12 to 15 in., compact............. 400

8 to 12 in., compact. . . . . . . . . . . 250

4 to $5 \mathrm{ft}$., compact, sheared............3500 3 to $4 \mathrm{ft}$., compact, sheared............25 00 30 to 36 in., compact, sheared.......... 1500 24 to 30 in., compact, sheared . . . . . . . 1250 18 to 24 in., compact, sheared ........ 600 15 to 18 in., compact, sheared........ 500 12 to 15 in., compact, sheared . . . . . . . 300 10 to 12 in., compact.............. 250

8 to 10 in., compact............... 200 pisifera plumosa aurea.

30 to 36 in., compact, sheared.......... 1500 18 to 24 in., compact, sheared . . . . . . . 600 15 to 18 in., compact, sheared........ 500 
Coniferous Evergreens, continued

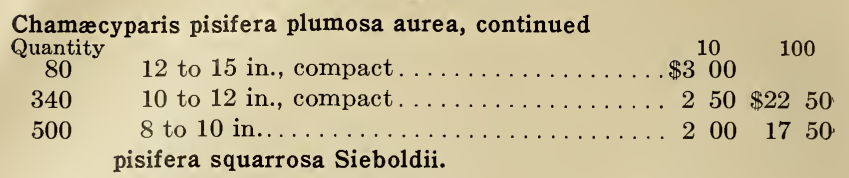

1530 to 36 in., very compact......................... 00

$18 \quad 18$ to 24 in., very compact...........6 600

$20 \quad 12$ to 15 in., compact............. 300 pisifera squarrosa Veitchii.

2 to $3 \mathrm{ft}$., very compact, sheared........15 00

18 to 24 in., very compact, sheared...... $750 \quad 6000$

15 to 18 in., very compact, sheared....... $500 \quad 4000$

12 to 15 in., compact. . . . . . . . . . $400 \quad 3500$

CUNNINGHAMIA lanceolata (sinensis).

25

25

CUPRESSUS sempervirens, Roylii, and stricta.

20

\section{JUNIPERUS chinensis albo-variegata.}

\section{PINUS DENSIFLORA (Japanese Red Pine).}

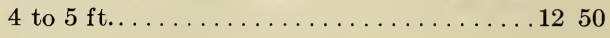

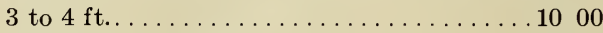

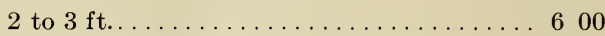

18 to 24 in.................... 500

12 to 15 in..................... 300

6 to $7 \mathrm{ft}$., very compact specimens.......... 10000

5 to $6 \mathrm{ft}$., very compact specimens........7500

4 to $5 \mathrm{ft}$., very compact specimens......6600

18 to 24 in., very compact specimens. . . . 1250

12 to 15 in., compact.............. 300

10 to 12 in., compact............. 250

\section{COMMUNIS.}

4 to $5 \mathrm{ft}$., very compact. . . . . . . . 1750

3 to $4 \mathrm{ft}$., very compact.............10 00

2 to $3 \mathrm{ft}$., very compact............6 60

18 to 24 in., compact............... 350 communis aurea.

30 - to 36 -in. spread, very heavy .........1500 24 - to 30 -in. spread, very heavy. . . . . . . 1000

12 - to 15 -in. spread................ 500 communis hibernica.

3 to $4 \mathrm{ft}$., compact. . . . . . . . . . . 1000

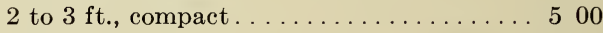

18 to 24 in..................... . 350

8 to 10 in................... 150

communis oblonga. 15 - to 18 -in. spread..... 500

Sabina. 10 - to 15 -in. spread. . . . . . . . . 500

Sabina tamariscifolia. 10- to 15-in. spread... . 500 squamata.

18- to 24-in. spread, heavy . . . . . . . . . 1000

10 - to 15 -in. spread............... 600

LIBOCEDRUS decurrens (Incense Cedar).

24 to 30 in., very compact............ 1000

15 to 18 in., stocky............. 750

15 to 18 in., stocky. . . . . . . . . . 500 excelsa (Bhotan Pine).

12 to 15 in.................... 350

montana. 12 to 18 in. ............6 60

2 to $3 \mathrm{ft}$., well branched..............6 $600 \quad 5000$

18 to 24 in., branched.............. $500 \quad 4000$

2 to $3 \mathrm{ft}$., branched.................. $1000 \quad 8000$

18 to 24 in., branched............... $750 \quad 6000$ 


\section{Coniferous Evergreens, continued}

Quantity Pinus Pinaster (Cluster Pine). $10 \quad 100$

$50 \quad 3$ to $4 \mathrm{ft}$., branched............... $\$ 2000$

$250 \quad 2$ to $3 \mathrm{ft} . \ldots \ldots \ldots \ldots \ldots \ldots \ldots \ldots \ldots 60 \ldots$

THUYA occidentalis.

$100 \quad 18$ to 24 in., compact..............6 600

$150 \quad 12$ to 15 in., compact............... $300 \quad 2500$ occidentalis elegantissima.

15 to 18 in., compact............. 500

10 to 15 in., compact............. 350

8 to 10 in.................... 250 occidentalis globosa.

18 to 24 in., very compact........... 1250

12 to $15 \mathrm{in}$, very compact..........5 00

10 to 12 in., compact............. 400

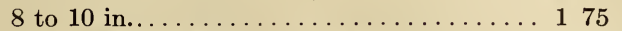
occidentalis plicata (Lobb's Arborvitæ).

15 to 18 in., compact.............. 500 occidentalis pumila.

15 to 18 in., very compact...........6 600

12 to 15 in., very compact.......... 500

10 to 12 in., very compact............ 350

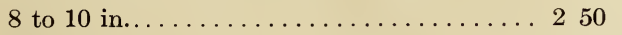

6 to 8 in.................. 150

occidentalis Reidii.

24 to 30 in., very compact........... 1250

18 to 24 in., compact............... 750

12 to 18 in., compact............. 500

10 to 12 in., compact............. 350

\section{ORIENTALIS AUREA CONSPICUA.}

5 to $6 \mathrm{ft}$., very compact specimens.......40 00

4 to $5 \mathrm{ft}$., very compact specimens....... 3000

3 to $4 \mathrm{ft}$, compact.................. 125010000

30 to 36 in., compact............... $1000 \quad 7500$

24 to 30 in., compact. . . . . . . . . . $600 \quad 5000$

12 to 15 in., compact............. 300

orientalis aurea nana.

165

1,300

30 to 36 in., very compact specimens. . ...20 $00 \quad 17500$

20 to 24 in., very compact............ $750 \quad 6000$

2008 to 10 in., compact..............2 $50 \quad 2000$

\section{ORIENTALIS AUREA PYRAMIDALIS.}

5 to $6 \mathrm{ft}$., very compact specimens.......40 00

4 to $5 \mathrm{ft}$., very compact specimens.......20 $00 \quad 15000$

3 to $4 \mathrm{ft}$, compact specimens . . . . . . . . $1000 \quad 7500$

30 to 36 in., compact specimens........ $800 \quad 6500$

18 to 24 in., compact............... $400 \quad 3500$

12 to 18 in., compact .............. $250 \quad 2000$ orientalis pyramidalis.

5 to $6 \mathrm{ft}$., compact specimens.......... 3000

4 to $5 \mathrm{ft}$., compact specimens . . . . . . . 22 5020000

3 to $4 \mathrm{ft}$., compact................. $1500 \quad 12500$

This is a very beautiful compact form.

Has stood $25^{\circ}$ below zero. Retains green

color during winter.

\section{Specimen Conifers}

We have some very handsome conifers, such as Chamæcyparis pisifera plumosa, Chamæcyparis pisifera plumosa aurea, Thuya orientalis aurea conspicua, Thuya orientalis aurea pyramidalis, Thuya orientalis Sieboldii, Thuya occidentalis Reidii, etc. Many of these specimens are over twenty-five years of age. As the plants have been several times transplanted they lift readily with a large ball of earth about the roots. Prices and specifications upon application. 


\section{ROSES}

\section{Strong Field-Grown}

For many years our Roses have been noted for their sturdiness and unusual vigor. Roses grown at Augusta are giving splendid results as far north as Canada.

The soil here is especially adapted to developing the Rose properly. Our one-year, field-grown plants equal the average two-year fieldgrown plants of the North and West.

NoтE.-The letter following the name of the rose denotes the class to which it belongs, viz: (T.) Tea, (H.T.) Hybrid Tea, (C.) China, (H. P.) Hybrid Perpetual, (N.) Noisette, (Poly.) Polyantha, (R.) Rugosa, (W.) Wichuraiana, (B.) Bourbon, (H.W.) Hybrid Wichuraiana.

\section{Budded on Manetti $\begin{gathered}\text { Price } \\ \text { per } 100\end{gathered}$}

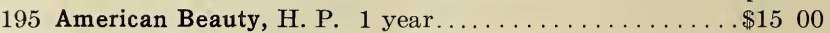

110 American Beauty, Climbing, Cl. H. P. 1 year . . . . . 1500

$40 \quad 2$ years ........ 1800

100 Baronne Rothschild, H. P. 2 years............. 1800

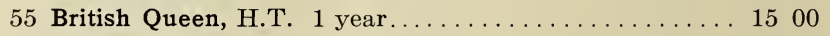

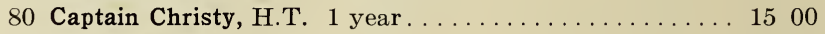

90 Etoile de France, H.T. 1 year............... 1500

25 Etoile de Lyon, T. 2 years.................. 1800

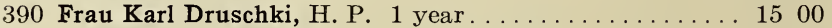

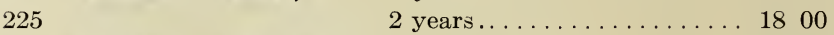

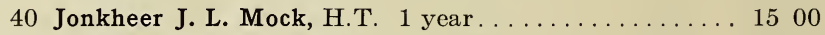

40 Kaiserin Augusta Victoria, Climbing, Cl. H.T. 1 year. . 1500

$25 \quad 2$ years... 1800

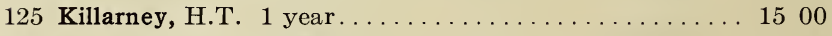

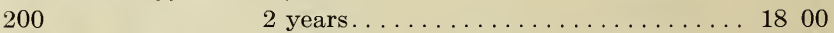

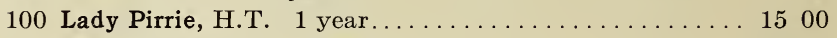

$60 \quad 2$ years................. 1800

70 La France, H.T. 1 year................... 1500

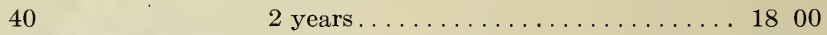

190 Marechal Niel, N. 1 year. . . . . . . . . . . . . . . 1500

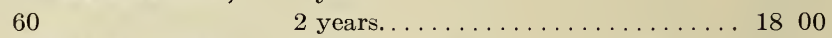

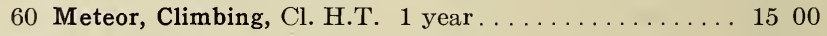

$20 \quad 2$ years ............ 1800

100 Mme. Caroline Testout, H.T. 1 year........... 1500

552 years............ 1800

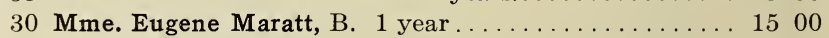

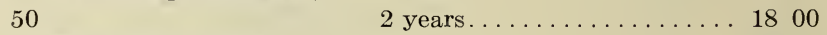

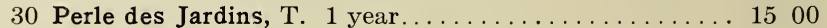

40 Perle des Jardins, Climbing, Cl. T. 1 year.......... 1500

$20 \quad 2$ years.......... 1800

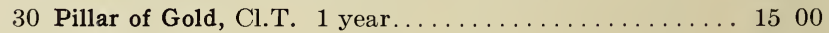

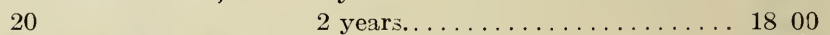

770 Pink Cherokee. 1 year................... 1500

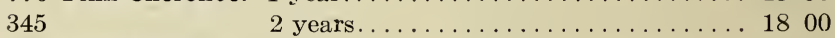

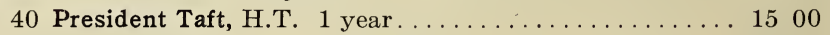

$20 \quad 2$ years................... 1800

240 Reine Marie Henriette, H.T. 1 year............ 1500

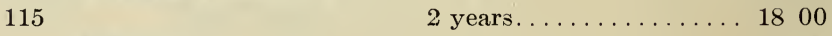

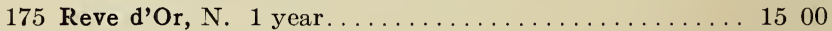

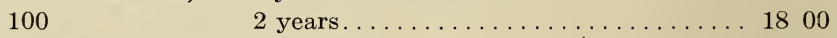

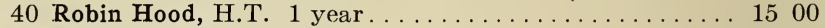

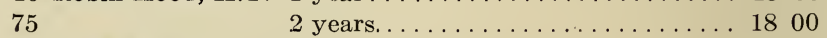

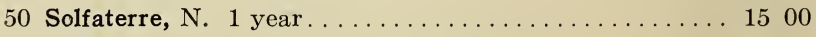

$40 \quad 2$ years................... 1800

65 Souv. de la Malmaison, Climbing, Cl. B. 1 year...... 1500

$85 \quad 2$ years...... 1800

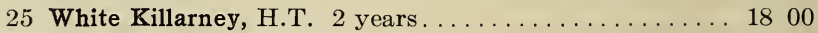

20 Wm. Allen Richardson, N. 1 year............ 1500

$5 \quad 2$ years.................. 1800

30 Souv. of Wootten, Climbing, Cl. H.T. 1 year........ 1500

$10 \quad 2$ years........ 1800 


\section{Roses on Own Roots $\begin{gathered}\text { Price } \\ \text { per } 100\end{gathered}$}

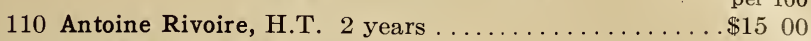

15 Archduke Charles, Bengal. 1 year ............. 1350

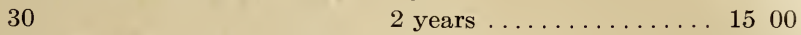

50 Banksia, White. 2 years ................. 1500

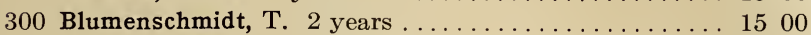

75 British Queen, H.T. 2 years ................ 1500

290 Clotilde Soupert, Climbing, Cl. Poly. 2 years . . . . . 1350

140 Col. R. S. Williamson, H.T. 2 years . . . . . . . . 1500

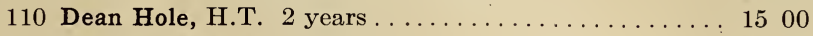

400 Dorothy Perkins, W. 2 years . . . . . . . . . . 1250

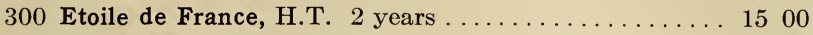

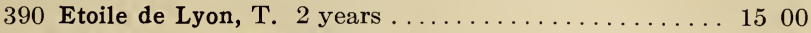

100 Freiherr von Marschall, T. 2 years ............ 1500

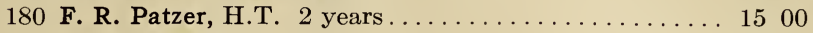

80 General MacArthur, H.T. 2 years........... 1500

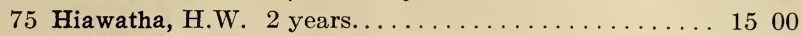

160 Helen Gould, H.T. 2 years .............. 1500

250 Herzogin Maria Antoinette, H.T. 2 years ......... 1500

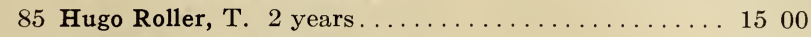

200 Jonkheer J. L. Mock, H.T. 2 years ........... 1500

40 Kaiserin Augusta Victoria, H.T. 1 year......... 1350

$225 \quad 2$ years......... 1500

20 Kaiserin Augusta Victoria, Climbing, Cl. H.T. 1 year . 1350

$150 \quad 2$ years. 1500

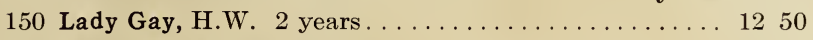

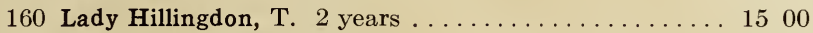

100 La France, H.T. 2 years . . . . . . . . . . . . 1500

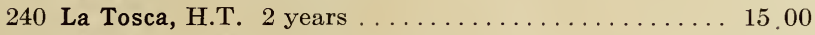

300 Maman Cochet, T. 2 years ................ 1500

135 Marie Van Houtte, T. 2 years ............. 1500

160 Marshall P. Wilder, H. P. 2 years ............ 1500

140 Meteor, H.T. 2 years .................. 1500

110 Mlle. Blanche Martignat, T. 2 years ........... 1500

40 Mme. Caroline Testout, H.T. 1 year .......... 1350

150 Mme. Eugene Maratt, B. 2 years . . . . . . . . . 1500

50 Mme. Francisca Kruger, T. 2 years .......... 1500

70 Mme. Helen Gould. 2 years . . . . . . . . . . . . 1500

125 Mme. Jules Grolez, H.T. 2 years . . . . . . . . 1500

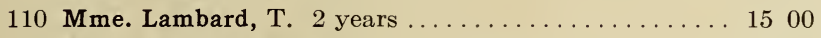

35 Mme. Melanie Soupert, H.T. 1 year .......... 1350

$110 \quad 2$ years ................... 1500

60 Mme. Segond Weber, H.T. 2 years ......... 1500

190 Mme. Valere Beaumez, N.T. 2 years............ 1500

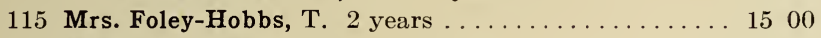

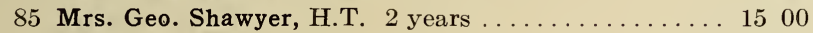

60 Papa Gontier, T. 2 years .................. 1500

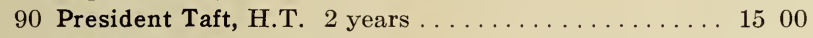

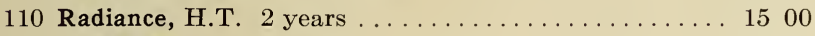

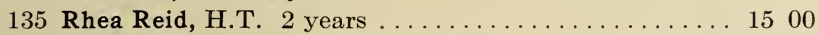

1,075 Rugosa rubra, R. 3 years, seedlings........... 1000

150 Silver Moon, H.W. 2 years . . . . . . . . . . . 1500

175 Souv. du Pres. Carnot, H.T. 2 years.......... 1500

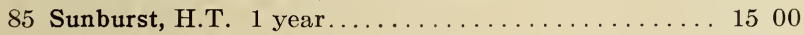

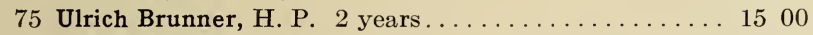

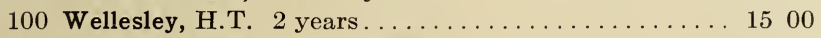

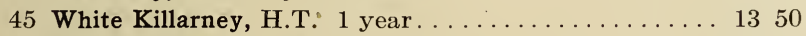

190 White Maman Cochet, T. 2 years............ 1500

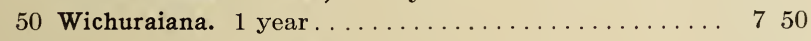

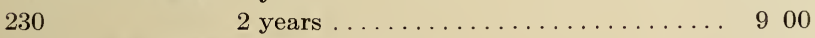

335 William Shean, H.T. 2 years.............. 1500

180 Yvonne Vacherot, H.T. 2 years............ 1500 


\section{INDEX}

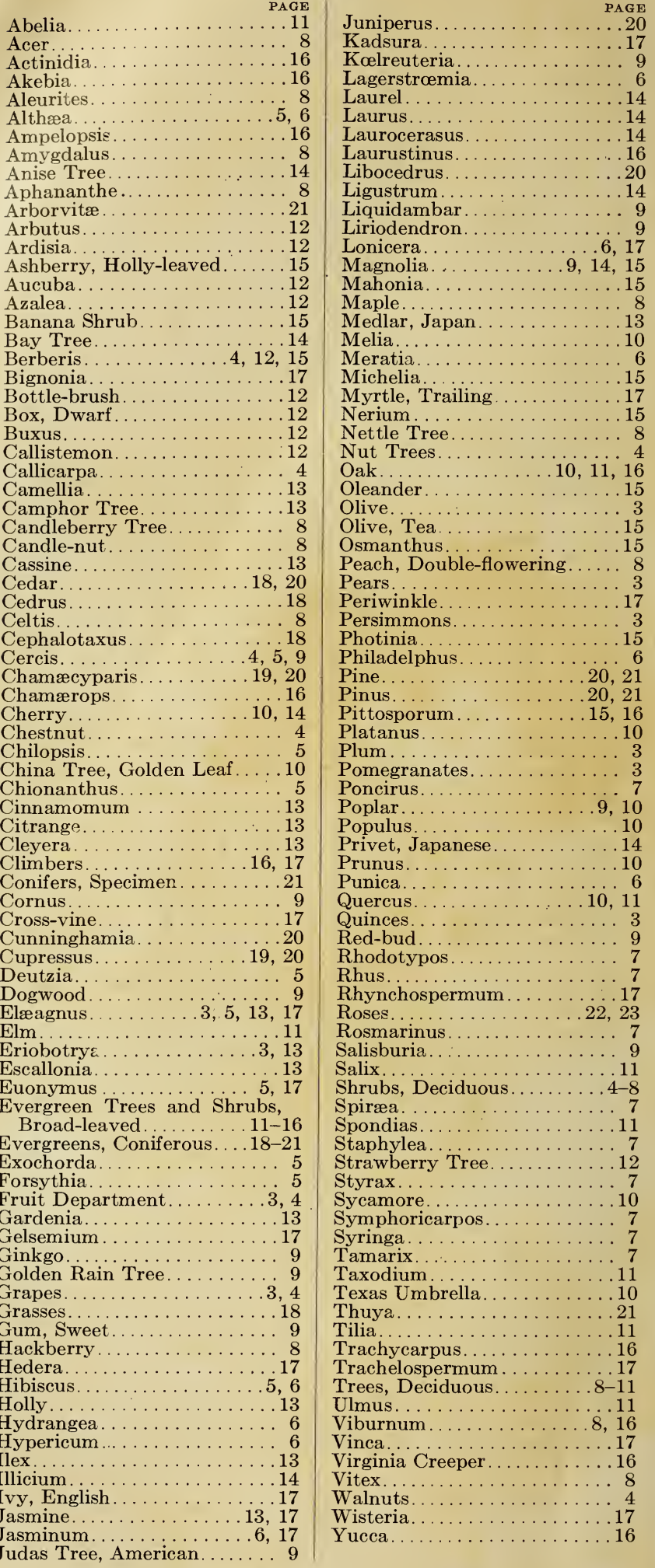




\section{NO SCALE OR DISEASE}

Our nurseries are inspected annually by the State Entomologist. A certificate of inspection is attached to every package that leaves our establishment.

\section{FUMIGATION}

We fumigate our stock with hydrocyanic acid gas before shipping, as required by state law, which assures freedom from insects or disease of any kind. 


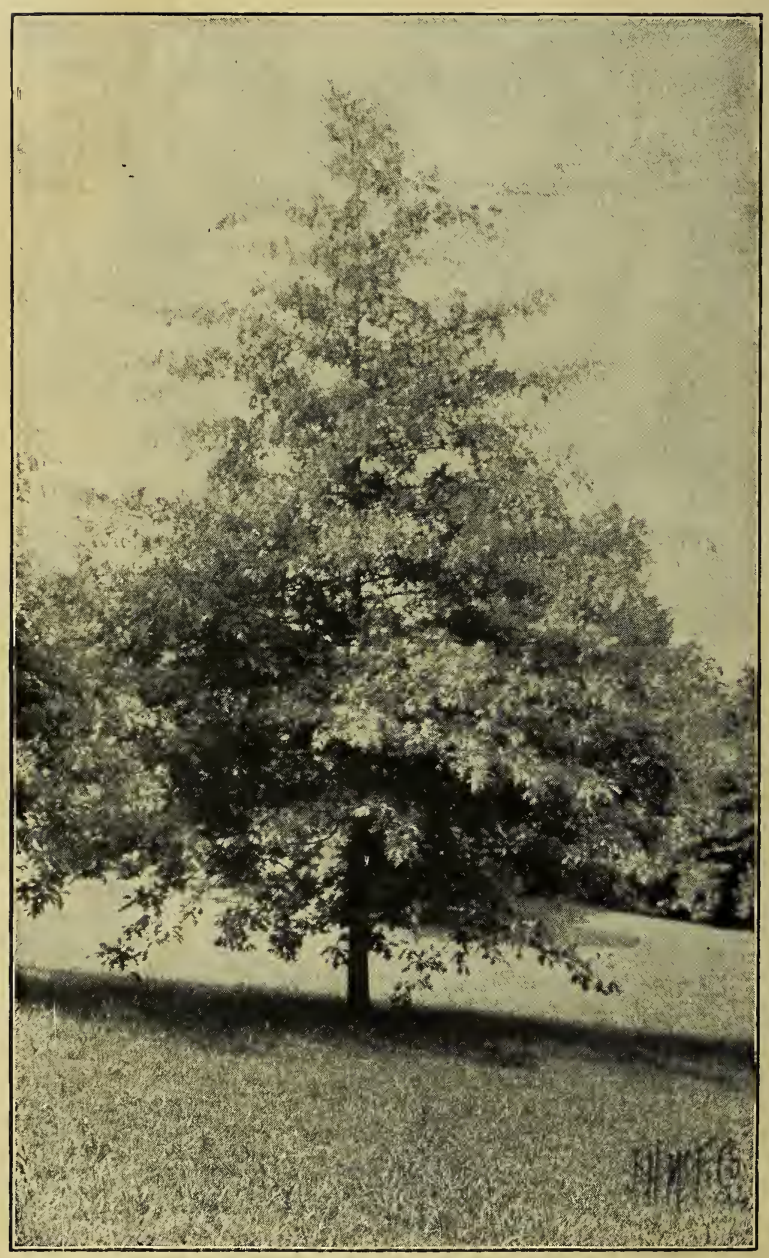

Quercus palustris (Pin Oak) 